\title{
Article \\ Scale and Scope of Gene-Alcohol Interactions in Chronic Pancreatitis: A Systematic Review
}

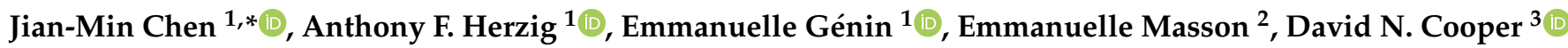 \\ and Claude Férec 1,2 \\ 1 EFS, Univ Brest, Inserm, UMR 1078, GGB, F-29200 Brest, France; anthony.herzig@inserm.fr (A.F.H.); \\ emmanuelle.genin@inserm.fr (E.G.); claude.ferec@univ-brest.fr (C.F.) \\ 2 Service de Génétique Médicale et de Biologie de la Reproduction, CHRU Brest, F-29200 Brest, France; \\ emmanuelle.masson@univ-brest.fr \\ 3 Institute of Medical Genetics, School of Medicine, Cardiff University, Cardiff CF10 3XQ, UK; \\ CooperDN@cardiff.ac.uk \\ * Correspondence: jian-min.chen@univ-brest.fr
}

Citation: Chen, J.-M.; Herzig, A.F.; Génin, E.; Masson, E.; Cooper, D.N.; Férec, C. Scale and Scope of Gene-Alcohol Interactions in Chronic Pancreatitis: A Systematic Review. Genes 2021, 12, 471. https://doi.org/ $10.3390 /$ genes 12040471

Academic Editor:

Selvarangan Ponnazhagan

Received: 17 February 2021

Accepted: 23 March 2021

Published: 25 March 2021

Publisher's Note: MDPI stays neutral with regard to jurisdictional claims in published maps and institutional affiliations.

Copyright: () 2021 by the authors. Licensee MDPI, Basel, Switzerland. This article is an open access article distributed under the terms and conditions of the Creative Commons Attribution (CC BY) license (https:// creativecommons.org/licenses/by/ $4.0 /)$.

\begin{abstract}
Background: Excessive alcohol consumption has long been known to be the primary cause of chronic pancreatitis $(\mathrm{CP})$ but genetic risk factors have been increasingly identified over the past 25 years. The scale and scope of gene-alcohol interactions in $\mathrm{CP}$ nevertheless remain unclear. Methods: All studies that had obtained genetic variant data concurrently on alcoholic CP (ACP) patients, non-ACP (NACP) patients and normal controls were collated. Employing normal controls as a common baseline, paired $\mathrm{OR}_{\mathrm{ACP}}$ and $\mathrm{OR}_{\mathrm{NACP}}$ (odds ratios associated with $\mathrm{ACP}$ and $\mathrm{NACP}$, respectively) values were calculated and used to assess gene-alcohol interactions. Results: Thirteen variants involving PRSS1, SPINK1, CTRC, CLDN2, CPA1, CEL and CTRB1-CTRB2, and varying from very rare to common, were collated. Seven variants had an $\mathrm{OR}_{\mathrm{ACP}}>\mathrm{OR}_{\mathrm{NACP}}$, which was regarded as an immediate indicator of gene-alcohol interactions in CP. Variants with an $\mathrm{OR}_{\mathrm{ACP}}<\mathrm{OR}_{\mathrm{NACP}}$ were also found to interact with alcohol consumption by virtue of their impact on age at first pancreatitis symptoms in ACP. Conclusions: This study revealed evidence for extensive gene-alcohol interactions in CP. Our findings lend support to the hypothesis that alcohol affects the expression of genetically determined $\mathrm{CP}$ and highlight a predominant role of weak-effect variants in the development of ACP.
\end{abstract}

Keywords: genetic predisposition to disease; gene dosage effect; genetic variation; genome-wide association study; human

\section{Introduction}

Although excessive alcohol consumption has long been known to be the primary cause of chronic pancreatitis (CP), its contribution to the etiology and development of pancreatitis is still shrouded in mystery in many respects [1-4]. Since the discovery of the first CP-causing variant, namely c.365G >A (p.Arg122His) in the PRSS1 gene (MIM\# 276000; encoding cationic trypsinogen) [5], one new puzzle has emerged pertaining to whether or how a particular genetic risk factor interacts with alcohol consumption to cause CP. For example, one of the most extensively studied genetic risk factors-c.101A $>\mathrm{G}$ (p.Asn34Ser) in the SPINK1 gene (MIM\# 167790; encoding pancreatic-specific trypsin inhibitor (PSTI)) [6] — was found to be overrepresented in alcoholic CP (ACP) patients; however, its detection rate in ACP patients was actually lower than that in non-ACP (NACP) patients [7-9], making it difficult to discern any gene-environment interactions $(G \times E)$ that might exist. Similar situations include, among others, a much lower detection rate of rare pathogenic CTRC (MIM\# 601405; encoding chymotrypsin C) or CPA1 (MIM\# 114850; encoding carboxypeptidase A1) variants in ACP patients than in NACP patients [10,11].

An interaction between alcohol consumption and the rs10273639-tagging common PRSS1-PRSS2 haplotype had however been suggested, firstly by the observation that the 
risk rs10273639C allele was found more frequently in ACP patients than in NACP patients and secondly by a case-only (i.e., ACP vs. NACP) analysis [12]. Recently, by fitting a more sophisticated model and by combining data from several studies, we provided compelling evidence for a synergistic interaction between the common PRSS1-PRSS2 haplotype and alcohol consumption [13]. PRSS1 was the first gene discovered to be responsible for CP [5]. Most pathogenic PRSS1 variants cause or predispose to CP by promoting increased activation or expression of trypsinogen [14], as exemplified by the p.Arg122His missense variant and trypsinogen gene duplication and triplication copy number variants $[5,15,16]$. PRSS2 encodes anionic trypsinogen (MIM\# 601564), the second major trypsinogen isoform after cationic trypsinogen. Multiple lines of evidence support the involvement of PRSS2 in $\mathrm{CP}$ (see Herzig et al. [13] and references therein), although no pathogenic missense variants in the gene have been reported to date [14].

In addition to gain-of-function PRSS1 missense and copy number variants, loss-offunction variants in the SPINK1 gene [6] and CTRC gene $[10,17]$ also predispose to CP by bringing about a gain of trypsin activity. Specifically, loss-of-function SPINK1 variants exert their effect by reducing the capability of PSTI-trypsin binding (see Szabo et al. [18] and references therein) whereas most loss-of-function CTRC variants increase trypsin activity by impairing (protective) trypsinogen degradation $[10,19]$. Together, genetic studies of the three genes have led to the identification of a trypsin-dependent pathological pathway in CP [20].

There is a pronounced dosage effect of the aforementioned rs10273639C risk allele on PRSS1/PRSS2 mRNA expression in human pancreatic tissue [12,13]. Given that uncontrolled trypsin expression/activity is central to CP pathogenesis $[5,12,15,21-25]$, the synergistic interaction revealed between the common PRSS1-PRSS2 haplotype and alcohol consumption [13] may serve as an important reference for unravelling the underlying mechanisms responsible for the $\mathrm{G} \times \mathrm{E}$ interactions in $\mathrm{CP}$.

The three trypsin-dependent pathway genes (PRSS1, SPINK1 and CTRC) are among the most extensively studied $\mathrm{CP}$ genes in the context of NACP as well as ACP. We propose that a systematic review and meta-analysis of the currently available genetic data, starting from a comparison of the risk (in terms of odds ratio (OR)) conferred upon ACP (termed $\mathrm{OR}_{\mathrm{ACP}}$ ) by known pathogenic variants in the trypsin-dependent pathway genes (as well as other $\mathrm{CP}$ susceptibility genes) with the corresponding risk conferred to NACP (termed $\mathrm{OR}_{\mathrm{NACP}}$ ), could shed new light on the scale and scope of $\mathrm{G} \times \mathrm{E}$ interactions in $\mathrm{CP}$. This study represents just such an attempt.

\section{Materials and Methods}

\subsection{Disease Definitions}

$\mathrm{ACP}$ was defined here as in the original publications despite slight differences in terms of the amount and duration of alcohol consumed as well as the ethnicity of the studied cohorts. For example, in most studies, ACP was attributed in relation to an alcohol intake of $\geq 80 \mathrm{~g} / \mathrm{d}$ for a male and $60 \mathrm{~g} / \mathrm{d}$ for a female for at least two years although both amount and duration of alcohol consumption were not specified in some studies. NACP and idiopathic chronic pancreatitis (ICP) were used here interchangeably. In principle, NACP was diagnosed in $\mathrm{CP}$ patients who were not known to have a positive family history and whose disease was not caused by known etiologies such as heavy drinking, autoimmune or obstructive factors.

\subsection{Research Strategy}

The outline of the research strategy is provided in Figure 1A. The key step was to generate paired $\mathrm{OR}_{\mathrm{ACP}}$ and $\mathrm{OR}_{\mathrm{NACP}}$ values for the previously reported variants in the three trypsin-dependent pathway genes as well as several other CP susceptibility genes. This was achieved through the re-analysis of available studies that had obtained variant data concurrently on ACP patients, NACP patients and normal controls, with normal controls being employed as a common baseline to calculate the respective ORs. In parallel to this main analysis, and in the context of the three trypsin-dependent pathway genes, we also compared the risk allele frequencies of informative variants in simultaneously 
analyzed normal and alcoholic controls. Alcoholic controls denote either subjects with alcohol dependence but without chronic pancreatitis or subjects with alcohol-associated liver cirrhosis. Normal controls denote healthy or population controls.

A

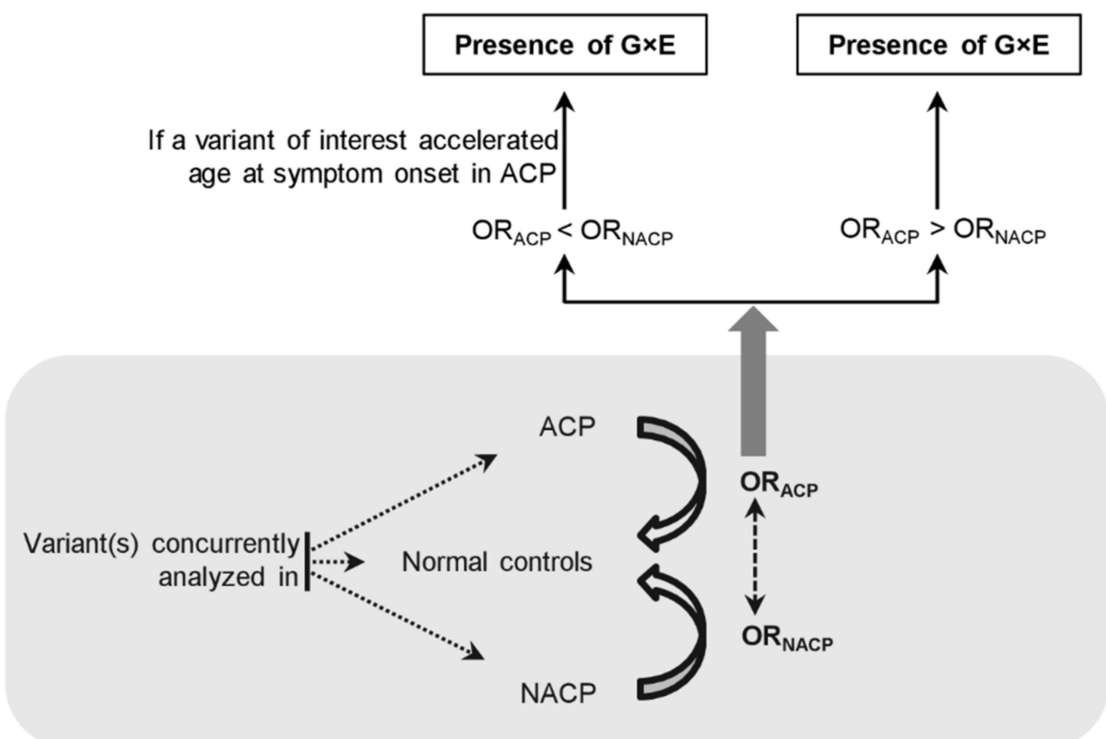

B

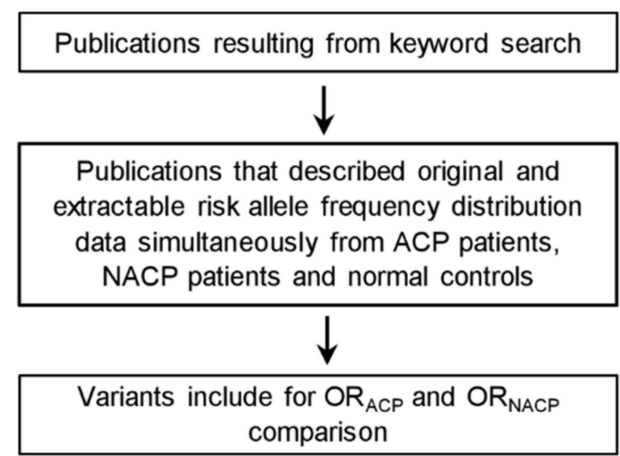

PRSS1

SPINK1

CTRC

$n=260$

$n=391$

$n=76$

$n=17$

$n=17$

$n=5$

$n=3$

$n=2$

$n=4$

Figure 1. (A) Outline of the research strategy. (B) Flow chart of the search and selection process for the studies used for the analysis in the context of the three trypsin-dependent pathway genes. ACP, alcoholic chronic pancreatitis; $\mathrm{G} \times \mathrm{E}$, gene-environment interaction; $\mathrm{NACP}$, non-alcoholic chronic pancreatitis; $\mathrm{OR}_{\mathrm{ACP}}$, odds ratio associated with $\mathrm{ACP} ; \mathrm{OR}_{\mathrm{NACP}}$, odds ratio associated with NACP.

The resulting paired $\mathrm{OR}_{\mathrm{ACP}}$ and $\mathrm{OR}_{\mathrm{NACP}}$ values were used firstly to evaluate the scale of $\mathrm{G} \times \mathrm{E}$ interactions in $\mathrm{CP}$. Thus, if a variant had an $\mathrm{OR}_{\mathrm{ACP}}>\mathrm{OR}_{\mathrm{NACP}}$, it was interpreted as denoting an interaction with alcohol consumption. When variants exhibited an $\mathrm{OR}_{\mathrm{ACP}}<\mathrm{OR}_{\mathrm{NACP}}$, a further literature search was performed with a view to establishing their impact on the age at symptom onset in ACP: if a given variant was shown to accelerate age at symptom onset in variant-positive $\mathrm{ACP}$ patients compared to variant-negative $\mathrm{ACP}$ patients, this was interpreted as denoting an interaction with alcohol consumption.

\subsection{Literature Searches and Selection Processes}

Literature searches, performed with the intention of generating paired $\mathrm{OR}_{\mathrm{ACP}}$ and $\mathrm{OR}_{\mathrm{NACP}}$ values, in the context of the PRSS1, SPINK1 and CTRC genes, respectively, employed keyword queries in "all fields" of PubMed, from August 2020 to November 2020 and were frozen on 20 November 2020. For each gene, different sets of keyword query were first performed, with the results from the different queries being combined to generate a 
single list of unique publications (for details, see Supplementary Figure S1). All keyword search-derived publications were manually reviewed; only those that described original and extractable risk allele frequency distribution data simultaneously from ACP patients, $\mathrm{NACP}$ patients and normal controls were retained for analysis. In cases of overlapping informative studies from the same group, it was the latest one that was used for analysis. In the context of additional $\mathrm{CP}$ genes, only the first disease association report that included variant data from $\mathrm{ACP}, \mathrm{NACP}$ and normal controls was used for analysis whenever possible; subsequent studies were briefly discussed regarding confirmation (or otherwise) of the first association report.

\subsection{Data Extraction}

All relevant data were manually extracted from the included studies.

\subsection{Statistical Analysis}

For a given variant (or aggregated variants), and in the case of single study-derived data, the $\mathrm{OR}_{\mathrm{ACP}}$ or $\mathrm{OR}_{\mathrm{NACP}}$, associated $95 \%$ confidence interval (CI), and related $\chi^{2}$ test of significance of the difference between risk allele frequencies, were calculated from the appropriate 2-by-2 contingency table in $\mathrm{R}$ [26]. A difference was regarded as being statistically significant when the $p$ value was $\leq 0.05$. If, for a given variant, data were available from $\geq 2$ studies, the variant was subject to meta-analysis with respect to the calculation of its OR, 95\% CI and $p$ values. Meta-analysis, heterogeneity analysis, forest plots and funnel plots were performed using Review Manager 5.3 software [27]. The Mantel-Haenszel fixed-effect model was used to compute the pooled OR in the absence of statistical heterogeneity; otherwise, the Mantel-Haenszel random-effect model was used. Heterogeneity was considered to be significant when the $p$ value for the test of heterogeneity was $<0.05$ or $I^{2}$ was $50 \%$ or more $[27,28]$. Funnel plots were performed only when the number of included studies that generated estimable ORs was $\geq 10$ [27,29].

This study essentially followed PRISMA (Preferred Reporting Items for Systematic Reviews and Meta-Analyses) guidelines [30]. The study was not registered in PROSPERO (an international database of prospectively registered systematic reviews), which does not allow the registration of already initiated studies [31]. It should be noted here that the validity of this study was not affected in any way by its non-registration in PROSPERO; all details of the study were fully provided.

\subsection{Variant Classification in Accordance with Allele Frequency}

Variants of interest were classified as very rare $(<0.001)$, rare (from 0.001 to $<0.005)$, low frequency (from 0.005 to 0.05 ) or common $(>0.05)$ in accordance with their allele frequencies in the studied normal controls, following the definitions of Manolio and colleagues [32].

\section{Results}

\subsection{Variants Included for Analysis}

In the context of the three trypsin-dependent pathway genes, the keyword searches yielded 260 PRSS1-related, 391 SPINK1-related and 76 CTRC-related publications (Supplementary Figure S1). Manual review of these publications in accordance with the criteria specified in Figure 1B identified 17 PRSS1-related (Supplementary Table S1), 17 SPINK1related (Supplementary Table S2) and 5 CTRC-related (Supplementary Table S3) studies that were then used for analysis. In the end, three distinct PRSS1 variants, two distinct SPINK1 variants, three distinct CTRC variants as well as one aggregate CTRC variant (all rare/very rare pathogenic variants in exons 2, 3 and 7), were retained for analysis (Table 1). It should be noted here that CTRC c.180C $>\mathrm{T}$ (p.Gly60Gly) was counted as two distinct variants; it was a common variant in the European and American populations $[17,33]$ but rare in the Chinese population [34]. See Supplementary Results, Supplementary Figures S2-S5 and Supplementary Tables S1-S4 for details about how these variants were selected and how their respective OR values were calculated. 
Table 1. Paired $\mathrm{OR}_{\mathrm{ACP}}$ and $\mathrm{OR}_{\mathrm{NACP}}$ values of the included PRSS1, SPINK1 and CTRC variants.

\begin{tabular}{|c|c|c|c|c|c|c|c|c|c|}
\hline Gene & Variant & $\begin{array}{c}\text { Number of } \\
\text { ACP/NACP/Normal } \\
\text { Controls }\end{array}$ & $\begin{array}{c}\text { Allele } \\
\text { Frequency in } \\
\text { ACP }\end{array}$ & $\begin{array}{c}\text { Allele } \\
\text { Frequency in } \\
\text { NACP }\end{array}$ & $\begin{array}{l}\text { Allele Frequency } \\
\text { in Normal } \\
\text { Controls }\end{array}$ & $\underset{p \text { Value }}{\mathrm{OR}_{\mathrm{ACP}}(95 \% \mathrm{CI})}$ & $\begin{array}{c}\mathrm{OR}_{\mathrm{NACP}}(95 \% \mathrm{CI}) ; \\
p \text { Value }\end{array}$ & Source of Data & $\begin{array}{c}\text { Data Point } \\
\text { Denoted in } \\
\text { Figure } 2\end{array}$ \\
\hline \multirow{2}{*}{ PRSS1 } & rs $10273639 \mathrm{C} / \mathrm{T}$ (C is the risk allele) & & $\begin{array}{c}65.0 \% \\
(3610 / 5556)\end{array}$ & $\begin{array}{c}53.6 \% \\
(4341 / 8094)\end{array}$ & & $\begin{array}{c}1.67(1.56-1.78) \\
p<0.00001\end{array}$ & $\begin{array}{c}1.28 \text { (1.17-1.40); } \\
p<0.00001\end{array}$ & $\begin{array}{l}\text { Directly taken from Herzig } \\
\text { et al. [13] }\end{array}$ & D3 \\
\hline & c.623G>C (p.Gly208Ala) & 206/715/1196 & $\begin{array}{c}4.4 \% \\
(18 / 412)\end{array}$ & $\begin{array}{c}4.2 \% \\
(60 / 1430)\end{array}$ & $\begin{array}{c}0.9 \% \\
(22 / 2392)\end{array}$ & $\begin{array}{l}4.92(2.62-9.26) \\
p=3.6 \times 10^{-7}\end{array}$ & $\begin{array}{l}4.72(2.88-7.72) \\
p=9.2 \times 10^{-11}\end{array}$ & Zou et al. [34] & D7 \\
\hline \multirow{2}{*}{ SPINK1 } & c.101A>G (p.Asn34Ser) & $1184 / 1441 / 4021$ & $\begin{array}{c}3.0 \% \\
(72 / 2368)\end{array}$ & $\begin{array}{c}5.8 \% \\
(168 / 2882)\end{array}$ & $\begin{array}{c}0.6 \% \\
(49 / 8042)\end{array}$ & $\begin{array}{c}4.55(3.08-6.72) \\
p<0.00001\end{array}$ & $\begin{array}{c}10.90(7.56-15.72) \\
p<0.00001\end{array}$ & $\begin{array}{l}\text { Meta-analysis of } 17 \text { studies } \\
\quad \text { (refer to Figure } \mathrm{S} 3 \text { ) }\end{array}$ & D11 \\
\hline & c. $194+2 \mathrm{~T}>\mathrm{C}$ & $206 / 715 / 1196$ & $\begin{array}{c}14.3 \% \\
(59 / 412)\end{array}$ & $\begin{array}{c}24.5 \% \\
(350 / 1430)\end{array}$ & $\begin{array}{c}0.5 \% \\
(13 / 2392)\end{array}$ & $\begin{array}{c}30.59(16.61-56.34) \\
p<2.2 \times 10^{-16}\end{array}$ & $\begin{array}{c}59.31 \\
(33.93-103.64) \\
p<2.2 \times 10^{-16}\end{array}$ & Zou et al. [34] & D13 \\
\hline \multirow{4}{*}{ CTRC } & $\begin{array}{c}\text { Aggregate rare/very rare } \\
\text { pathogenic variants in exons 2, } 3 \\
\text { and } 7\end{array}$ & $348 / 758 / 2804$ & $\begin{array}{c}1.9 \% \\
(13 / 696) \\
\end{array}$ & $\begin{array}{c}1.8 \% \\
(27 / 1516) \\
\end{array}$ & $\begin{array}{c}0.4 \% \\
(25 / 5608) \\
\end{array}$ & $\begin{array}{c}4.25(2.16-8.35) \\
p=2.0 \times 10^{-5}\end{array}$ & $\begin{array}{c}4.05(2.34-7.00) \\
p=2.1 \times 10^{-7}\end{array}$ & Rosendahl et al. [10] & D6 \\
\hline & c.760C $>\mathrm{T}$ (p.Arg254Trp) & $788 / 1563 / 4349$ & $\begin{array}{c}0.8 \% \\
(12 / 1576) \\
\end{array}$ & $\begin{array}{c}0.4 \% \\
(13 / 3126) \\
\end{array}$ & $\begin{array}{c}0.3 \% \\
(22 / 8698) \\
\end{array}$ & $\begin{array}{c}2.87(1.34-6.14) \\
p=0.007\end{array}$ & $\begin{array}{c}1.98(1.03-3.81) \\
p=0.04\end{array}$ & $\begin{array}{c}\text { Meta-analysis of four studies } \\
\text { (refer to Figure S5) }\end{array}$ & D5 \\
\hline & c. $180 \mathrm{C}>\mathrm{T}$ (p.Gly60Gly) & $236 / 302 / 1013$ & $\begin{array}{c}20.8 \% \\
(98 / 472)\end{array}$ & $\begin{array}{c}12.4 \% \\
(75 / 604)\end{array}$ & $\begin{array}{c}10.8 \% \\
(219 / 2026)\end{array}$ & $\begin{array}{c}2.16(1.66-2.81) \\
p=7.7 \times 10^{-7}\end{array}$ & $\begin{array}{c}1.17(0.89-1.55) \\
p=0.36\end{array}$ & LaRush et al. [33] & D2 \\
\hline & c.180C > T (p.Gly60Gly) & $206 / 715 / 1196$ & $\begin{array}{l}0.5 \% \\
(2 / 412)\end{array}$ & $\begin{array}{c}1.1 \% \\
(16 / 1430)\end{array}$ & $\begin{array}{c}0.1 \% \\
(3 / 2392)\end{array}$ & $\begin{array}{c}3.88(0.65-23.32) \\
p=0.33\end{array}$ & $\begin{array}{c}9.01(2.62-30.98) \\
p=7.4 \times 10^{-5}\end{array}$ & Zou et al. [34] & D9 \\
\hline
\end{tabular}

$\mathrm{ACP}$, alcoholic chronic pancreatitis; $\mathrm{CI}$, confidence interval; $\mathrm{NACP}$, non-alcoholic chronic pancreatitis; $\mathrm{OR}_{\mathrm{ACP}}$, odds ratio associated with $\mathrm{ACP}$; $\mathrm{OR}$ NACP, odds ratio associated with $\mathrm{NACP}$. 
There were four other CP genes/loci for which the first disease association report concurrently analyzed ACP patients, NACP patients and normal controls, yielding three distinct informative variants (i.e., CLDN2 rs7057398, CEL-HYB1 and CTRB1-CTRB2 rs8055167) and one aggregate informative variant (i.e., all CPA1 variants with apparent activity $<20 \%$ ) (Table 2). A detailed description of these four variants is provided in the Supplementary Results.

In summary, a total of 13 variants were included for analysis.

\subsection{Evidence Suggesting Extensive $G \times$ E Interactions in $C P$}

The paired $\mathrm{OR}_{\mathrm{ACP}}$ and $\mathrm{OR}_{\mathrm{NACP}}$ values of the 13 included variants, either newly calculated here or directly taken from the corresponding original reports, are provided in Tables 1 and 2. Up to seven variants had an $\mathrm{OR}_{\mathrm{ACP}}>\mathrm{OR}_{\mathrm{NACP}}$ (5 in Table 1 and 2 in Table 2), suggesting the presence of $\mathrm{G} \times \mathrm{E}$ interactions between the respective variants and alcohol consumption. Three of the seven variants, namely PRSS1 rs10273639C, SPINK1 c.101A>G (p.Asn34Ser) and aggregate pathogenic rare/very rare variants in exons 2, 3 and 7 of the CTRC gene, were also concurrently analyzed in alcoholic controls and normal controls (See Supplementary Results, Supplementary Figure S6 and Supplementary Table S5 for details about how these variants were selected). None of them showed significant allele difference between the two control datasets (Table 3).

As for the 6 variants that had an $\mathrm{OR}_{\mathrm{ACP}}<\mathrm{OR}_{\mathrm{NACP}}(4$ in Table 1 and 2 in Table 2), we searched for reports in which the age at symptom onset was informative in variant-positive and -negative ACP patients. Four reports were found to be informative with respect to distinct variants. Three of them [35-37] reported no significant difference in age at symptom onset between SPINK1 c.101A>G (p.Asn34Ser)-positive and -negative ACP patients; the remaining one [38] reported no significant difference with respect to two distinct CPA1 variants, p.Arg254Trp and c.738_761del. However, all these studies were limited by sample size (at most 124 patients were analyzed). We also found two reports that were informative for aggregate variants. Using the Kaplan-Meier model, Zou and colleagues showed that aggregate pathogenic genotypes involving either PRSS1, SPINK1, CTRC and/or CFTR (MIM\# 602421; encoding cystic fibrosis transmembrane conductance regulator) genes were associated with a significant acceleration in age at symptom onset in ACP $(p<0.001$; see Supplementary Figure S5 in the original report [34]) (NB, the pathogenic genotypes disproportionately involved PRSS1 and SPINK1 variants of strong genetic effect as defined below). The recent Lewis study demonstrated that the median age at symptom onset in ACP patients (defined as an alcohol consumption of $>4$ drinks per day) with a pathogenic SPINK1 variant was 39 years whereas that in SPINK1 variant-negative ACP patients was 45 years, although the difference did not achieve statistical significance [39]. Here, it is pertinent to note that Lewis and colleagues also analyzed a subgroup of CP patients termed "light to moderate drinkers" (defined as an alcohol consumption of $\leq 4$ drinks per day) and found a statistically younger median age at symptom onset in SPINK1 variant-positive patients as compared to SPINK1 variant-negative patients ( 24 vs. 50 years). Details of the pathogenic SPINK1 variants were not made available in this latter report, but most, if not all, of them should fall into the category of variants of strong genetic effect as defined below. Taken together, these findings supported the presence of $\mathrm{G} \times \mathrm{E}$ interactions in cases wherein a $\mathrm{G} \times \mathrm{E}$ interaction was not immediately evident from a direct comparison of paired $\mathrm{OR}_{\mathrm{ACP}}$ and $\mathrm{OR}_{\mathrm{NACP}}$ values.

\subsection{Inter-and Intra-Variant Comparison of the Paired $O R_{A C P}$ and $O R_{N A C P}$ Values Revealed a Dichotomized Genetic Effect}

To better understand the ground rules for $\mathrm{G} \times \mathrm{E}$ interactions in $\mathrm{CP}$, we next performed an inter- and intra-variant comparison of the paired $\mathrm{OR}_{\mathrm{ACP}}$ and $\mathrm{OR}_{\mathrm{NACP}}$ values. Using $\mathrm{OR}_{\mathrm{NACP}}$ as the baseline genetic effect for comparison, we observed a clear and consistent pattern of genetic effect-dependent dichotomization: thus, variants with $\mathrm{OR}_{\mathrm{NACP}}$ ranging from 1.09 to 4.72 were invariably found more frequently in ACP than in NACP, whereas variants with $\mathrm{OR}_{\mathrm{NACP}}$ ranging from 5.20 to 59.31 were invariably found more frequently in $\mathrm{NACP}$ than in $\mathrm{ACP}$, with an $\mathrm{OR}_{\mathrm{NACP}}$ value of $\sim 5$ appearing to be the threshold (Figure 2). 
Based upon this observation, and by reference to the gene effect classifications by Manolio and colleagues [32], we defined here an $\mathrm{OR}_{\mathrm{NACP}}$ value of $<5$ as a weak genetic effect and an $\mathrm{OR}_{\mathrm{NACP}}$ value of $\geq 5$ as a strong genetic effect. In other words, variants with a strong genetic effect were found more frequently in NACP than in $\mathrm{ACP}$, whereas variants with a weak genetic effect were found more frequently in ACP than in NACP.

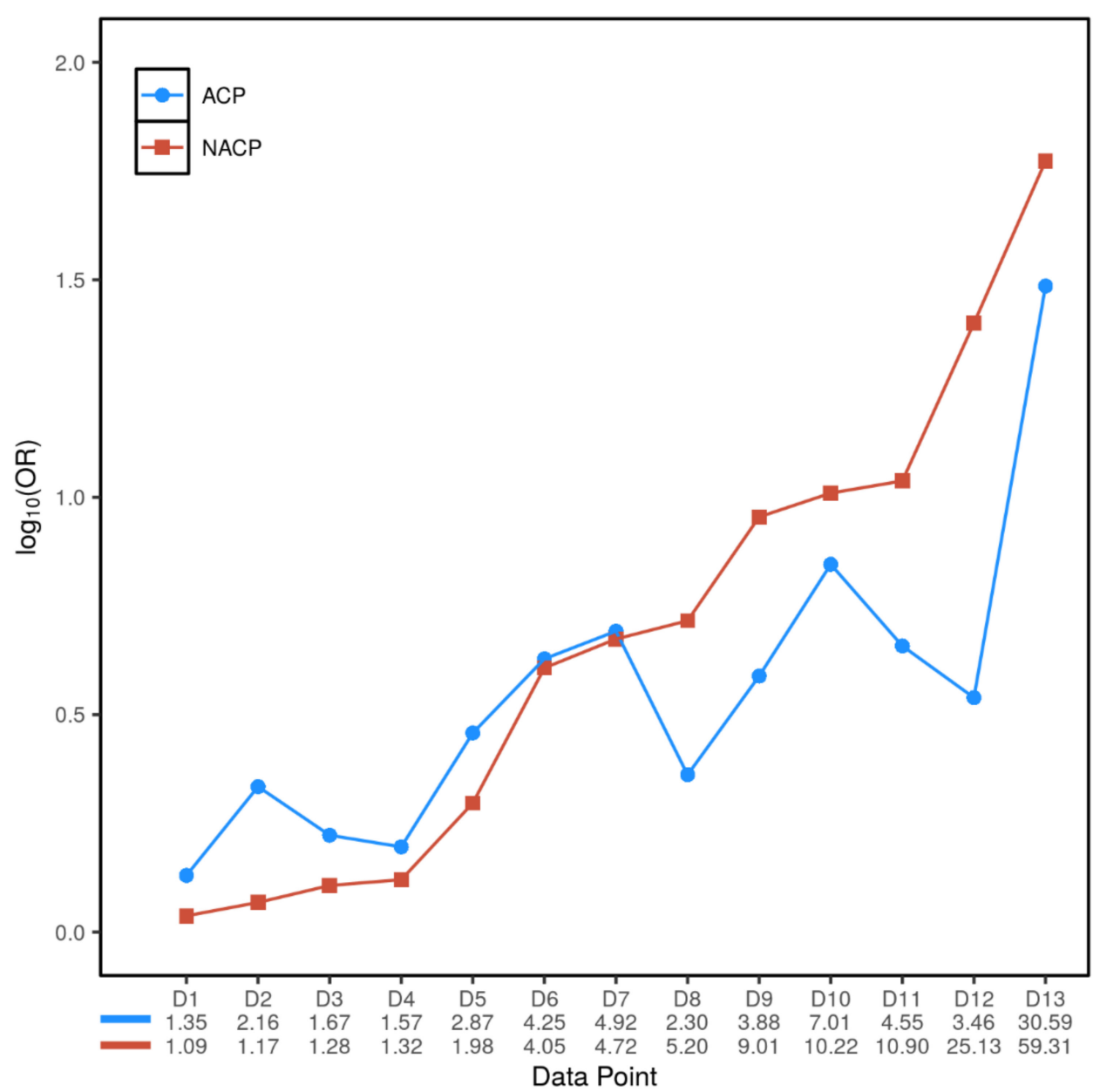

Figure 2. Inter- and intra-variant comparisons of the genetic effects of the included variants on $\mathrm{ACP}$ (expressed as $\mathrm{OR}_{\mathrm{ACP}}$ ) and NACP (expressed as $\mathrm{OR}_{\mathrm{NACP}}$ ). On the $X$-axis, the data points (denoted by D1-D13) were arranged in accordance with the $\mathrm{OR}_{\mathrm{NACP}}$ values of the variants listed in Tables 1 and 2, going from the smallest to the largest. ACP, alcoholic chronic pancreatitis; NACP, non-alcoholic chronic pancreatitis; $\mathrm{OR}_{\mathrm{ACP}}$, odds ratio associated with $\mathrm{ACP} ; \mathrm{OR}_{\mathrm{NACP}}$, odds ratio associated with NACP. 
Table 2. Paired $\mathrm{OR}_{\mathrm{ACP}} \mathrm{vs.} \mathrm{OR}_{\mathrm{NACP}}$ values of included variants from four additional chronic pancreatitis susceptibility genes.

\begin{tabular}{|c|c|c|c|c|c|c|c|c|c|}
\hline $\begin{array}{l}\text { Gene or } \\
\text { Locus }\end{array}$ & Variant & $\begin{array}{c}\text { Number of } \\
\text { ACP/NACP/Normal } \\
\text { Controls }\end{array}$ & $\begin{array}{l}\text { Allele Frequency } \\
\text { in ACP }\end{array}$ & $\begin{array}{l}\text { Allele Frequency } \\
\text { in NACP }\end{array}$ & $\begin{array}{l}\text { Allele Frequency } \\
\text { in Normal } \\
\text { Controls }\end{array}$ & $\begin{array}{l}\mathrm{OR}_{\mathrm{ACP}}(95 \% \mathrm{CI}) \\
\quad p \text { Value }\end{array}$ & $\begin{array}{c}\mathrm{OR}_{\mathrm{NACP}}(95 \% \mathrm{CI}) \\
p \text { Value }\end{array}$ & Source of Data & $\begin{array}{c}\text { Data Point } \\
\text { Denoted in } \\
\text { Figure } 2\end{array}$ \\
\hline \multirow{2}{*}{ CLDN2 } & rs12688220 & & $42.7 \%$ & $32.2 \%$ & & Not available & Not available & $\begin{array}{l}\text { Directly taken from } \\
\text { Whitcomb et al. [12] }\end{array}$ & \\
\hline & rs7057398 & & & & & $1.57(1.14-2.18)$ & $1.32(1.15-1.51)$ & $\begin{array}{l}\text { Directly taken from } \\
\text { Derikx et al. [40] }\end{array}$ & $\mathrm{D} 4$ \\
\hline CPA1 & $\begin{array}{l}\text { Aggregate variants with } \\
\text { apparent activity }<20 \%\end{array}$ & $456 / 944 / 3938$ & $\begin{array}{c}0.2 \% \\
(2 / 912)\end{array}$ & $\begin{array}{c}1.5 \% \\
(29 / 1888)\end{array}$ & $\begin{array}{c}0.06 \% \\
(5 / 7878)\end{array}$ & $\begin{array}{c}3.46(0.67-17.84) \\
\quad p=0.34\end{array}$ & $\begin{array}{c}25.13(9.72-65.02) \\
p<2.2 \times 10^{-16}\end{array}$ & $\begin{array}{c}\text { Witt et al. [11]; only } \\
\text { German data were used. }\end{array}$ & D12 \\
\hline$C E L$ & CEL-HYB1 & & & & & $\begin{array}{c}2.3(1.2-4.4) \\
p=0.016\end{array}$ & $\begin{array}{c}5.2(3.2-8.5) \\
p=1.2 \times 10^{-11}\end{array}$ & $\begin{array}{l}\text { Directly taken from Fjeld } \\
\text { et al. [41] }\end{array}$ & D8 \\
\hline $\begin{array}{l}\text { CTRB1- } \\
\text { CTRB2 }\end{array}$ & rs8055167 & & & & & $1.35(1.23-1.60)$ & $1.09(0.82-1.44)$ & $\begin{array}{l}\text { Directly taken from } \\
\text { Rosendahl et al. [42] }\end{array}$ & D1 \\
\hline
\end{tabular}

$\mathrm{ACP}$, alcoholic chronic pancreatitis; $\mathrm{CI}$, confidence interval; $\mathrm{NACP}$, non-alcoholic chronic pancreatitis; $\mathrm{OR}_{\mathrm{ACP}}$, odds ratio associated with $\mathrm{ACP}$; $\mathrm{OR}_{\mathrm{NACP}}$, odds ratio associated with $\mathrm{NACP}$.

Table 3. Comparison of the risk allele frequencies of the indicated variants between alcoholic controls and normal controls.

\begin{tabular}{|c|c|c|c|c|c|c|}
\hline Gene & Variant & $\begin{array}{c}\text { Number of Alcoholic } \\
\text { Controls/Normal } \\
\text { Controls }\end{array}$ & $\begin{array}{l}\text { Allele Frequency in } \\
\text { Alcoholic Controls }\end{array}$ & $\begin{array}{l}\text { Allele Frequency in } \\
\text { Normal Controls }\end{array}$ & $p$ Value & Source of Data \\
\hline PRSS1 & rs10273639 (C is the risk allele) & $1530 / 2825$ & $57.7 \%(1766 / 3060)$ & $58.5 \%(3305 / 5650)$ & 0.85 & $\begin{array}{l}\text { Derikx et al. [40] (only data from } \\
\text { the German subjects were used) }\end{array}$ \\
\hline SPINK1 & c.101A>G (p.Asn34Ser) & $305 / 941$ & $0.49 \%(3 / 610)$ & $0.43 \%(8 / 1882)$ & 0.91 & $\begin{array}{l}\text { Meta-analysis of four studies } \\
\text { (refer to Figure S6). }\end{array}$ \\
\hline CTRC & $\begin{array}{l}\text { Aggregate pathogenic } \\
\text { rare/very rare variants in } \\
\text { exons } 2,3 \text { and } 7\end{array}$ & $432 / 2804$ & $0.46 \%(4 / 864)$ & $0.45 \%(25 / 5608)$ & 1.00 & Rosendahl et al. [10] \\
\hline
\end{tabular}




\section{Discussion}

Prompted by findings from our recent meta- and re-analyses [13], we have herein embarked on a new analysis of published data with a view to being able to ascertain the scale and basic ground rules of $\mathrm{G} \times \mathrm{E}$ interactions in $\mathrm{CP}$. The premise behind this attempt was that the wealth of genetic and clinical data which has accumulated over the past decades might harbor valuable information that could potentiate epidemiological exploration.

Mindful of the differences in disease definition between different studies in terms of the amount of alcohol consumed and the duration of heavy drinking [34], we opted to use only studies that analyzed variant(s) of interest concurrently in ACP patients, NACP patients and normal controls, with normal controls being employed as a common baseline to allow the simultaneous calculation of $\mathrm{OR}_{\mathrm{ACP}}$ and $\mathrm{OR}_{\mathrm{NACP}}$ values (Figure 1). A higher $\mathrm{OR}_{\mathrm{ACP}}$ than $\mathrm{OR}_{\mathrm{NACP}}$, which was observed in 7 of the 13 re-analyzed variants, was regarded as an immediate indicator of $\mathrm{G} \times \mathrm{E}$ interactions in $\mathrm{CP}$. Herein, it should be emphasized that we also collated variants that were concurrently analyzed in alcoholic and normal controls in the context of the three trypsin-dependent pathway genes. The respective risk allele frequencies of the three resulting variants, which collectively involved the PRSS1, SPINK1 and CTRC genes and whose allele frequencies in normal controls varied from rare to common, were remarkably similar between the two control datasets (Table 3). This allowed us to formally exclude the (albeit inherently unlikely) possibility that a higher OR in ACP than in NACP was actually due to an intrinsic association of the corresponding variant with alcohol consumption. As for variants with a higher $\mathrm{OR}_{\mathrm{NACP}}$ than $\mathrm{OR}_{\mathrm{ACP}}$, we also found strong evidence to support the presence of $\mathrm{G} \times \mathrm{E}$ interactions; multiple such variants impacted on age at first pancreatitis symptoms in ACP.

The extensive scale of $\mathrm{G} \times \mathrm{E}$ interactions in $\mathrm{CP}$ has received strong support from a mechanistic standpoint. Except for the PRSS1 c.263G >C (p.Gly208Ala) variant, which may involve mutation-induced misfolding and consequent endoplasmic reticulum stress owing to its negative effect on protein secretion [43], all the distinct PRSS1, SPINK1 and CTRC variants (or a cis-linked variant in cases such as PRSS1 rs10273639 [44] and SPINK1 c.101A>G (p.Asn34Ser) [45]) listed in Table 1 are thought to predispose to CP through their action on the trypsin-dependent pathway of pathology [20]. The recently discovered CTRB1-CTRB2 inversion polymorphism, tagged by rs8055167 (Table 2), affects protective trypsinogen degradation, thereby ensuring that it should be assigned to the trypsin-dependent pathway [42]. As mentioned earlier, there is a pronounced dosage effect of the rs10273639C risk allele on PRSS1/PRSS2 mRNA expression in human pancreatic tissue [12,13]; and a synergistic interaction between the risk allele and alcohol consumption has been formally demonstrated [13]. Moreover, and most importantly, mice that express PRSS1 Arg122His developed more severe pancreatitis after ethanol feeding [23].

The causal variant underlying the association with $C P$ at the CLDN2 locus remains to be identified, although the risk genotypes have been linked to ectopic expression of CLDN2 in pancreatic acinar cells [12]. Of the functionally defective CPA1 variants, the most frequently found variant in NACP patients, c.768C $>\mathrm{G}$ (p.Asn256Lys) [11], causes digestive enzyme misfolding and $C P$ in mice [46]. The CEL-HYB1 allele [41] also appears to cause proteotoxic misfolding owing to missense variants present in the breakpoint junction region of the allele [47]. It should be remembered that the PRSS1 c.263G $>$ C (p.Gly208Ala) variant may also involve a misfolding pathway that is distinct from the trypsin-dependent pathway [43]. Indeed, the misfolding-dependent pathway is now recognized as an independent mechanism underlying CP [48]. Recently, ethanol feeding was found to accelerate pancreatitis progression in CPA1 Asn256Lys mutant mice [49].

Despite the heterogeneity in relation both to the genes involved and the risk allele frequencies in normal controls, the re-analyzed variants exhibited a clear and consistent pattern of genetic effect-dependent dichotomization (Figure 2). Here, one may argue that of the seven variants with an $\mathrm{OR}_{\mathrm{ACP}}>\mathrm{OR}_{\mathrm{NACP}}$, a statistically significant $\mathrm{G} \times \mathrm{E}$ interaction was demonstrated only for rs10273639C [13] and CTRC c.180C $>$ T (p.Gly60Gly) in the context of the LaRush study [33], as evidenced by the non-overlapping 95\% CIs (Table 1). By contrast, 
the other five variants with an $\mathrm{OR}_{\mathrm{ACP}}>\mathrm{OR}_{\mathrm{NACP}}$ invariably showed overlapping $95 \%$ CIs. Given the clear and consistent pattern of genetic effect-dependent dichotomization exhibited by all analyzed variants (Figure 2), we assume that the absence of statistical significance in most cases was due to a lack of statistical power. Moreover, even in the two cases showing a statistically significant $\mathrm{G} \times \mathrm{E}$ interaction, the absolute differences between the respective $\mathrm{OR}_{\mathrm{ACP}}$ and $\mathrm{OR}_{\mathrm{NACP}}$ values were small. Importantly, these consistent observations with nevertheless subtle differences are consistent with a hypothesis about $\mathrm{G} \times \mathrm{E}$ interactions in $\mathrm{CP}$, which was originally postulated by Lankisch and colleagues 20 years ago, in the absence of genetic data; having simply evaluated the impact of alcohol intake on the clinical course of $\mathrm{CP}$, they presciently proposed that common underlying genetic defects exist as the basis of most $\mathrm{CP}$, with environmental factors such as alcohol consumption influencing the expression of the disease [50]. Therefore, it appears that whilst $\mathrm{G} \times \mathrm{E}$ interactions in $\mathrm{CP}$ are extensive, they are limited in degree. Additionally, the genetic effect-dependent dichotomization of the re-analyzed variants clearly demonstrate that, as compared to NACP, ACP is more often associated with variants of small genetic effect.

An additional observation merits special mention. Variants having strong effects (i.e., $\mathrm{OR}_{\mathrm{NACP}}$ of $>5$ ) tend to be rare/very rare whereas variants having weak effects (i.e., $\mathrm{OR}_{\mathrm{NACP}}$ of $<5$ ) tend to be common. Consistent with this general trend, CTRC c.180C $>\mathrm{T}$ (p.Gly60Gly) had an $\mathrm{OR}_{\mathrm{NACP}}$ of 9.01 when it was a rare variant [34] (in the Chinese population) but had an $\mathrm{OR}_{\mathrm{NACP}}$ of 1.17 when it was a common variant (in the North American population) [33] (Table 1). This is consistent with our increasing appreciation of ethnic differences in terms of genetic susceptibility to CP [51-53] and highlights the importance of the use of ethnically matched controls for genetic association and replication studies.

Our study has several limitations. First and foremost, this study was by no means comprehensive. For example, the CFTR gene was not included in the analysis in part due to its extremely high allelic heterogeneity. Secondly, as for the included variants, sample size was quite small in several instances, and this was perhaps the cause of several nonsignificant associations with ACP or NACP. Thirdly, we would like to reiterate that there were inter-study differences in terms of the $\mathrm{ACP}$ and $\mathrm{NACP}$ definitions employed although we consider it unlikely that these limitations would have affected the main conclusions drawn owing to the use of paired data in each included study. Finally, it is important to point out that we had to limit our $\mathrm{G} \times \mathrm{E}$ interaction analysis to the $\mathrm{ACP}$ context since genetic data on a subgroup of CP patients termed "light to moderate drinkers" [39] have only just begun to emerge. Nonetheless, we surmise that it may be possible to extrapolate from general principles derived from the study of $\mathrm{ACP}$ to gene-alcohol interactions in $\mathrm{CP}$ as a whole.

\section{Conclusions}

By means of a systematic review, we have uncovered evidence for extensive albeit limited $\mathrm{G} \times \mathrm{E}$ interactions in $\mathrm{CP}$ and demonstrated a clear and consistent pattern of genetic effect-dependent dichotomization of the re-analyzed variants. Our findings lend strong support to the hypothesis that alcohol affects the expression of genetically determined $\mathrm{CP}$ and highlight a predominant role of variants with a weak genetic effect in the development of ACP. This study also strengthens our appreciation of $\mathrm{CP}$ as a multigenic and multifactorial disease and highlights the challenges ahead in terms of variant detection, risk assessment and disease prevention in the age of personalized medicine.

Supplementary Materials: The following are available online at https:/ / www.mdpi.com/2073-4 425/12/4/471/s1, Supplementary Results, Figure S1: Sets and outcomes of the keyword search in "All Fields" of PubMed with respect to PRSS1-, SPINK1- and CTRC-related publications (frozen on 20 November 2020), Figure S2: Meta-analysis of the association between the risk allele of PRSS1 c.365G >A (p.Arg122His) and alcoholic chronic pancreatitis (A) or non-alcoholic chronic pancreatitis (B), Figure S3: Meta-analysis of the association between the risk allele of SPINK1 c.101A $>\mathrm{G}$ (p.Asn34Ser) and alcoholic chronic pancreatitis (A) or non-alcoholic chronic pancreatitis (B), Figure S4: Funnel plots corresponding to data presented in Supplementary Figure S3, Figure S5: Meta-analysis 
of the association between the risk allele of CTRC c.760C >T (p.Arg254Trp) and alcoholic chronic pancreatitis (A) or non-alcoholic chronic pancreatitis (B), Figure S6: Comparison of the risk allele frequencies of SPINK1 c.101A >G (p.Asn34Ser) in alcoholic controls (Experimental) and normal controls (Control) by means of meta-analysis, Table S1: PRSS1-related studies used for analysis, Table S2: SPINK1-related studies used for analysis, Table S3: CTRC-related studies used for analysis, Table S4: Pathogenic variants in exons 2, 3 and 7 of the CTRC gene in German ACP patients, NACP patients and normal controls, Table S5: Pathogenic variants in exons 2, 3 and 7 of the CTRC gene in German alcoholic controls and normal controls.

Author Contributions: Conceptualization, J.-M.C. and C.F.; methodology, J.-M.C., A.F.H. and E.G.; validation, A.F.H., E.G., E.M., D.N.C. and C.F.; formal analysis, J.-M.C. and A.F.H.; investigation, J.-M.C. and E.M.; data curation, J.-M.C. and E.M.; writing-original draft preparation, J.-M.C.; writing-review and editing, J.-M.C., A.F.H., E.G., E.M., D.N.C. and C.F.; visualization, J.-M.C. and A.F.H.; supervision, C.F.; project administration, J.-M.C. and C.F.; funding acquisition, J.-M.C., E.G. and C.F. All authors agreed to be accountable for all aspects of the work in ensuring that questions related to the accuracy or integrity of any part of the work are appropriately investigated and resolved. All authors have read and agreed to the published version of the manuscript.

Funding: This research was funded by the Institut National de la Santé et de la Recherche Médicale (INSERM), France. The funding body did not play any role in the study design, collection, analysis, and interpretation of data or the writing of the article and the decision to submit it for publication.

Institutional Review Board Statement: Not applicable.

Informed Consent Statement: Not applicable.

Data Availability Statement: All data relevant to the study are included in the article and uploaded as supplementary information.

Acknowledgments: We are grateful to the various authors who published studies that contributed the data that we used for our re-analysis.

Conflicts of Interest: The authors declare no conflict of interest.

\section{References}

1. Kleeff, J.; Whitcomb, D.C.; Shimosegawa, T.; Esposito, I.; Lerch, M.M.; Gress, T.; Mayerle, J.; Drewes, A.M.; Rebours, V.; Akisik, F.; et al. Chronic pancreatitis. Nat. Rev. Dis. Primers 2017, 3, 17060. [CrossRef]

2. Singhvi, A.; Yadav, D. Myths and realities about alcohol and smoking in chronic pancreatitis. Curr. Opin. Gastroenterol. 2018, 34, 355-361. [CrossRef] [PubMed]

3. Mayerle, J.; Sendler, M.; Hegyi, E.; Beyer, G.; Lerch, M.M.; Sahin-Tóth, M. Genetics, cell biology, and pathophysiology of pancreatitis. Gastroenterology 2019, 156, 1951-1968.e1. [CrossRef]

4. Hegyi, P.; Párniczky, A.; Lerch, M.M.; Sheel, A.R.; Rebours, V.; Forsmark, C.E.; Del Chiaro, M.; Rosendahl, J.; De-Madaria, E.; Szücs, Á.; et al. International consensus guidelines for risk factors in chronic pancreatitis. Recommendations from the Working Group for the International Consensus Guidelines for Chronic Pancreatitis in collaboration with the International Association of Pancreatology, the American Pancreatic Association, the Japan Pancreas Society, and European Pancreatic Club. Pancreatology 2020, 20, 579-585. [CrossRef]

5. Whitcomb, D.C.; Gorry, M.C.; Preston, R.; Furey, W.; Sossenheimer, M.J.; Ulrich, C.D.; Martin, S.P.; Gates, L.K., Jr.; Amann, S.T.; Toskes, P.P.; et al. Hereditary pancreatitis is caused by a mutation in the cationic trypsinogen gene. Nat. Genet. 1996, 14, 141-145. [CrossRef] [PubMed]

6. Witt, H.; Luck, W.; Hennies, H.C.; Classen, M.; Kage, A.; Lass, U.; Landt, O.; Becker, M. Mutations in the gene encoding the serine protease inhibitor, Kazal type 1 are associated with chronic pancreatitis. Nat. Genet. 2000, 25, 213-216. [CrossRef] [PubMed]

7. Witt, H.; Luck, W.; Becker, M.; Böhmig, M.; Kage, A.; Truninger, K.; Ammann, R.W.; O'Reilly, D.; Kingsnorth, A.; Schulz, H.-U.; et al. Mutation in the SPINK1 trypsin inhibitor gene, alcohol use, and chronic pancreatitis. JAMA 2001, 285, 2716-2717. [CrossRef]

8. Aoun, E.; Chang, C.-C.H.; Greer, J.B.; Papachristou, G.I.; Barmada, M.M.; Whitcomb, D.C. Pathways to injury in chronic pancreatitis: Decoding the role of the high-risk SPINK1 N34S haplotype using meta-analysis. PLoS ONE 2008, 3, e2003. [CrossRef]

9. Di Leo, M.; Bianco, M.; Zuppardo, R.A.; Guslandi, M.; Calabrese, F.; Mannucci, A.; Neri, T.M.; Testoni, P.A.; Leandro, G.; Cavestro, G.M. Meta-analysis of the impact of SPINK1 p.N34S gene variation in Caucasic patients with chronic pancreatitis. An update. Dig. Liver Dis. 2017, 49, 847-853. [CrossRef]

10. Rosendahl, J.; Witt, H.; Szmola, R.; Bhatia, E.; Ózsvári, B.; Landt, O.; Schulz, H.-U.; Gress, T.M.; Pfutzer, R.H.; Löhr, M.; et al. Chymotrypsin C (CTRC) variants that diminish activity or secretion are associated with chronic pancreatitis. Nat. Genet. 2008, 40, 78-82. [CrossRef] [PubMed] 
11. Witt, H.; Beer, S.; Rosendahl, J.; Chen, J.-M.; Chandak, G.R.; Masamune, A.; Bence, M.; Szmola, R.; Oracz, G.; Macek, M.J.; et al. Variants in CPA1 are strongly associated with early onset chronic pancreatitis. Nat. Genet. 2013, 45, 1216-1220. [CrossRef]

12. Whitcomb, D.C.; Alzheimer's Disease Genetics Consortium; LaRusch, J.; Krasinskas, A.M.; Klei, L.; Smith, J.P.; Brand, R.E.; Neoptolemos, J.P.; Lerch, M.M.; Tector, M.; et al. Common genetic variants in the CLDN2 and PRSS1-PRSS2 loci alter risk for alcohol-related and sporadic pancreatitis. Nat. Genet. 2012, 44, 1349-1354. [CrossRef]

13. Herzig, A.F.; Génin, E.; Cooper, D.N.; Masson, E.; Férec, C.; Chen, J.-M. Role of the common PRSS1-PRSS2 haplotype in alcoholic and non-alcoholic chronic pancreatitis: Meta- and re-analyses. Genes 2020, 11, 1349. [CrossRef] [PubMed]

14. Genetic Risk Factors in Chronic Pancreatitis. Available online: http://www.Pancreasgenetics.Org/index.Php (accessed on 16 February 2021).

15. Le Maréchal, C.; Masson, E.; Chen, J.-M.; Morel, F.; Ruszniewski, P.; Levy, P.; Férec, C. Hereditary pancreatitis caused by triplication of the trypsinogen locus. Nat. Genet. 2006, 38, 1372-1374. [CrossRef]

16. Masson, E.; Le Maréchal, C.; Chandak, G.R.; Lamoril, J.; Bezieau, S.; Mahurkar, S.; Bhaskar, S.; Reddy, D.N.; Chen, J.-M.; Férec, C. Trypsinogen copy number mutations in patients with idiopathic chronic pancreatitis. Clin. Gastroenterol. Hepatol. 2008, 6, 82-88. [CrossRef] [PubMed]

17. Masson, E.; Chen, J.M.; Scotet, V.; Le Maréchal, C.; Férec, C. Association of rare chymotrypsinogen C (CTRC) gene variations in patients with idiopathic chronic pancreatitis. Hum. Genet. 2008, 123, 83-91. [CrossRef]

18. Szabó, A.; Toldi, V.; Gazda, L.D.; Demcsák, A.; Tőzsér, J.; Sahin-Tóth, M. Defective binding of SPINK1 variants is an uncommon mechanism for impaired trypsin inhibition in chronic pancreatitis. J. Biol. Chem. 2021, 296, 100343. [CrossRef]

19. Beer, S.; Zhou, J.; Szabó, A.; Keiles, S.; Chandak, G.R.; Witt, H.; Sahin-Tóth, M. Comprehensive functional analysis of chymotrypsin C (CTRC) variants reveals distinct loss-of-function mechanisms associated with pancreatitis risk. Gut 2013, 62, 1616-1624. [CrossRef] [PubMed]

20. Hegyi, E.; Sahin-Tóth, M. Genetic risk in chronic pancreatitis: The trypsin-dependent pathway. Dig. Dis. Sci. 2017, 62, 1692-1701. [CrossRef]

21. Masson, E.; Chen, J.-M.; Cooper, D.N.; Férec, C. PRSS1 copy number variants and promoter polymorphisms in pancreatitis: Common pathogenetic mechanism, different genetic effects. Gut 2018, 67, 592-593. [CrossRef]

22. Gui, F.; Zhang, Y.; Wan, J.; Zhan, X.; Yao, Y.; Li, Y.; Haddock, A.N.; Shi, J.; Guo, J.; Chen, J.; et al. Trypsin activity governs increased susceptibility to pancreatitis in mice expressing human PRSS1 ${ }^{\mathrm{R} 122 \mathrm{H}}$. J. Clin. Investig. 2020, 130, 189-202. [CrossRef]

23. Huang, H.; Swidnicka-Siergiejko, A.K.; Daniluk, J.; Gaiser, S.; Yao, Y.; Peng, L.; Zhang, Y.; Liu, Y.; Dong, M.; Zhan, X.; et al Transgenic expression of PRSS1 ${ }^{\text {R122H }}$ sensitizes mice to pancreatitis. Gastroenterology 2020, 158, 1072-1082.e7. [CrossRef] [PubMed]

24. Jancsó, Z.; Sahin-Tóth, M. Mutation that promotes activation of trypsinogen increases severity of secretagogue-induced pancreatitis in mice. Gastroenterology 2020, 158, 1083-1094. [CrossRef]

25. Wan, J.; Haddock, A.; Edenfield, B.; Ji, B.; Bi, Y. Transgenic expression of human PRSS2 exacerbates pancreatitis in mice. Gut 2020, 69, 2051-2052. [CrossRef] [PubMed]

26. R Core Team. R: A Language and Environment for Statistical Computing; R Foundation for Statistical Computing: Vienna, Austria, 2018; Available online: https: / /www.R-project.org (accessed on 16 February 2021).

27. Review Manager (RevMan). Version 5.3. Copenhagen: The Nordic Cochrane Centre, T.C.C. 2014. Available online: https: / / review-manager.software.informer.com/5.3/ (accessed on 16 February 2021).

28. Sedgwick, P.; Marston, L. How to read a funnel plot in a meta-analysis. BMJ 2015, 351, h4718. [CrossRef]

29. Sterne, J.A.C.; Sutton, A.J.; Ioannidis, J.P.A.; Terrin, N.; Jones, D.R.; Lau, J.; Carpenter, J.; Rücker, G.; Harbord, R.M.; Schmid, C.H.; et al. Recommendations for examining and interpreting funnel plot asymmetry in meta-analyses of randomised controlled trials. BMJ 2011, 343, d4002. [CrossRef] [PubMed]

30. Moher, D.; Liberati, A.; Tetzlaff, J.; Altman, D.G.; The PRISMA Group. Preferred reporting items for systematic reviews and meta-analyses: The PRISMA statement. PLoS Med. 2009, 6, e1000097. [CrossRef]

31. PROSPERO (International Prospective Register of Systematic Reviews). Available online: https://www.Crd.York.Ac.Uk/ prospero/ (accessed on 16 February 2021).

32. Manolio, T.A.; Collins, F.S.; Cox, N.J.; Goldstein, D.B.; Hindorff, L.A.; Hunter, D.J.; McCarthy, M.I.; Ramos, E.M.; Cardon, L.R.; Chakravarti, A.; et al. Finding the missing heritability of complex diseases. Nature 2009, 461, 747-753. [CrossRef] [PubMed]

33. LaRusch, J.; Lozano-Leon, A.; Stello, K.; Moore, A.; Muddana, V.; O'Connell, M.; Diergaarde, B.; Yadav, D.; Whitcomb, D.C. The common chymotrypsinogen C (CTRC) variant G60G (c.180T) increases risk of chronic pancreatitis but not recurrent acute pancreatitis in a North American population. Clin. Transl. Gastroenterol. 2015, 6, e68. [CrossRef]

34. Zou, W.-B.; Tang, X.-Y.; Zhou, D.-Z.; Qian, Y.-Y.; Hu, L.-H.; Yu, F.-F.; Yu, D.; Wu, H.; Deng, S.-J.; Lin, J.-H.; et al. SPINK1, PRSS1, CTRC, and CFTR genotypes influence disease onset and clinical outcomes in chronic pancreatitis. Clin. Transl. Gastroenterol. 2018, 9, 204. [CrossRef]

35. Schneider, A.; Pfützer, R.H.; Barmada, M.M.; Slivka, A.; Martin, J.; Whitcomb, D.C. Limited contribution of the SPINK1 N34S mutation to the risk and severity of alcoholic chronic pancreatitis: A report from the United States. Dig. Dis. Sci. 2003, 48, 1110-1115. [CrossRef]

36. Cichoż-Lach, H.; Michalak, M.; Lis, E.; Wojcierowski, J.; Kowalik, A.; Słomka, M.; Korolczuk, A. The N34S mutation of the SPINK1 gene and alcoholic chronic pancreatitis. Pol. Arch. Med. Wewn. 2012, 122, 277-283. [CrossRef] [PubMed] 
37. Madro, A.; Ciesielka, M.; Celinski, K.; Slomka, M.; Czechowska, G.; Kurzepa, J.; Kaszelan-Szczerbinska, B.; Buszewicz, G.; Madro, $\mathrm{R}$. The genetic predisposition and its impact on the diabetes mellitus development in patients with alcoholic chronic pancreatitis. Gastroenterol. Res. Pract. 2015, 2015, 309156. [CrossRef] [PubMed]

38. Cichoz-Lach, H.; Michalak-Wojnowska, M.; Lis-Janczarek, E.; Wojcierowski, J.; Hydzik, M. Do CTRC mutations affect the development of alcoholic chronic pancreatitis and its course among poles: Preliminary study. Adv. Clin. Exp. Med. 2019, 28, 307-312. [CrossRef] [PubMed]

39. Lewis, M.D.; Talluri, J.; Wilcox, C.M.; Abberbock, J.N.; Tang, G.; Conwell, D.L.; Banks, P.A.; Cote, G.A.; Sherman, S.; Alkaade, S.; et al. Differences in age at onset of symptoms, and effects of genetic variants, in patients with early vs late-onset idiopathic chronic pancreatitis in a North American cohort. Clin. Gastroenterol. Hepatol. 2021, 19, 349-357. [CrossRef]

40. Derikx, M.H.; Kovacs, P.; Scholz, M.; Masson, E.; Chen, J.-M.; Ruffert, C.; Lichtner, P.; Morsche, R.H.M.T.; Cavestro, G.M.; Férec, C.; et al. Polymorphisms at PRSS1-PRSS2 and CLDN2-MORC4 loci associate with alcoholic and non-alcoholic chronic pancreatitis in a European replication study. Gut 2015, 64, 1426-1433. [CrossRef] [PubMed]

41. Fjeld, K.; Weiss, F.U.; Lasher, D.; Rosendahl, J.; Chen, J.-M.; Johansson, B.B.; Kirsten, H.; Ruffert, C.; Masson, E.; Steine, S.J.; et al. A recombined allele of the lipase gene CEL and its pseudogene CELP confers susceptibility to chronic pancreatitis. Nat. Genet. 2015, 47, 518-522. [CrossRef] [PubMed]

42. Rosendahl, J.; Kirsten, H.; Hegyi, E.; Kovacs, P.; Weiss, F.U.; Laumen, H.; Lichtner, P.; Ruffert, C.; Chen, J.-M.; Masson, E.; et al. Genome-wide association study identifies inversion in the CTRB1-CTRB2 locus to modify risk for alcoholic and non-alcoholic chronic pancreatitis. Gut 2018, 67, 1855-1863. [CrossRef] [PubMed]

43. Schnúr, A.; Beer, S.; Witt, H.; Hegyi, P.; Sahin-Tóth, M. Functional effects of 13 rare PRSS1 variants presumed to cause chronic pancreatitis. Gut 2014, 63, 337-343. [CrossRef]

44. Boulling, A.; Sato, M.; Masson, E.; Génin, E.; Chen, J.-M.; Férec, C. Identification of a functional PRSS1 promoter variant in linkage disequilibrium with the chronic pancreatitis-protecting rs10273639. Gut 2015, 64, 1837-1838. [CrossRef]

45. Boulling, A.; Masson, E.; Zou, W.; Paliwal, S.; Wu, H.; Issarapu, P.; Bhaskar, S.; Génin, E.; Cooper, D.N.; Li, Z.; et al. Identification of a functional enhancer variant within the chronic pancreatitis-associated SPINK1 c.101A >G (p.Asn34Ser)-containing haplotype. Hum. Mutat. 2017, 38, 1014-1024. [CrossRef]

46. Hegyi, E.; Sahin-Tóth, M. Human CPA1 mutation causes digestive enzyme misfolding and chronic pancreatitis in mice. Gut 2019, 68, 301-312. [CrossRef]

47. Cassidy, B.M.; Zino, S.; Fjeld, K.; Molven, A.; Lowe, M.E.; Xiao, X. Single nucleotide polymorphisms in CEL-HYB1 increase risk for chronic pancreatitis through proteotoxic misfolding. Hum. Mutat. 2020, 41, 1967-1978. [CrossRef]

48. Sahin-Tóth, M. Genetic risk in chronic pancreatitis: The misfolding-dependent pathway. Curr. Opin. Gastroenterol. 2017, 33, 390-395. [CrossRef] [PubMed]

49. Orekhova, A.; Geisz, A.; Sahin-Tóth, M. Ethanol feeding accelerates pancreatitis progression in CPA1 N256K mutant mice. Am. J. Physiol. Gastrointest Liver Physiol. 2020, 318, G694-G704. [CrossRef]

50. Lankisch, M.R.; Imoto, M.; Layer, P.; DiMagno, E.P. The Effect of small amounts of alcohol on the clinical course of chronic pancreatitis. Mayo Clin. Proc. 2001, 76, 242-251. [CrossRef]

51. Zou, W.-B.; Boulling, A.; Masamune, A.; Issarapu, P.; Masson, E.; Wu, H.; Sun, X.-T.; Hu, L.-H.; Zhou, D.-Z.; He, L.; et al. No association between CEL-HYB hybrid allele and chronic pancreatitis in Asian populations. Gastroenterology 2016, 150, 1558-1560.e5. [CrossRef] [PubMed]

52. Tang, X.-Y.; Zou, W.-B.; Masson, E.; Hu, L.-H.; Férec, C.; Chen, J.-M.; Li, Z.-S.; Liao, Z. The CTRB1-CTRB2 risk allele for chronic pancreatitis discovered in European populations does not contribute to disease risk variation in the Chinese population due to near allele fixation. Gut 2018, 67, 1368-1369. [CrossRef]

53. Lasher, D.; Szabó, A.; Masamune, A.; Chen, J.-M.; Xiao, X.; Whitcomb, D.C.; Barmada, M.M.; Ewers, M.; Ruffert, C.; Paliwal, S.; et al. Protease-sensitive pancreatic lipase variants are associated with early onset chronic pancreatitis. Am. J. Gastroenterol. 2019, 114, 974-983. [CrossRef] [PubMed] 